\title{
FIVE CASES OF ACUTE INFECTIVE POLYNEURITIS (GUILLAIN-BARRÉ SYNDROME) IN CHILDREN
}

\author{
BY \\ PAMELA AYLETT \\ From the West Middlesex Hospital
}

(RECEIVED FOR PUBLICATION MAY 13, 1954)

Guillain, Barré and Strohl (1916) described a syndrome which they believed to be new. Their findings were based on the study of two soldiers complaining of abnormal sensations in the feet, followed by weakness of the legs and difficulty in walking. Later the legs and then the arms became paralysed. In neither patient was there preceding illness or fever and both made a complete recovery. Lumbar puncture produced a cerebrospinal fluid with normal pressure and cell count but containing increased protein, in one case $250 \mathrm{mg}$. and in the other $85 \mathrm{mg}$. per $100 \mathrm{ml}$.

Similar cases were also described in England by Holmes (1917) and by Bradford, Bashford and Wilson (1918). They did not, however, give cerebrospinal fluid protein levels. The latter workers claimed to have produced a similar disease in monkeys by subdural inoculation of material from fatal cases. The condition came to be known in English writings as acute infective polyneuritis, although the infective nature was never confirmed experimentally by later workers.

The first reported case of the syndrome in a child was that of Monnier-Vinard (1925). Taylor and McDonald (1932) described 16 cases of which two were in children. Ansay (1937) stated that the syndrome was rare in children and reported a case in a boy of $8 \frac{1}{2}$ years. Van Bogaert, Philips, Radermecker and Verschraegen (1938) reported a small epidemic of cases of which six were in children. Debré and Thieffry (1951) discussed the features of 32 personal cases in children and thought that the frequency and clinical picture of the condition in childhood were insufficiently recognized.

The disease in childhood seems to have been little described in the English literature, although there are papers in American, French and other journals. Petch (1949) described eight cases of which one was in a child.

\section{Case Reports}

Case 1.-A girl aged 16 months was admitted on January 9, 1952, with a history of being miserable and unwell for 16 days. At first she had wanted to be nursed and was happier when off her feet. Seven days before admission she began to hold on to objects in walking and tended to fall over. Then she cried when her legs were touched and gradually 'lost the strength of them'. At times she had seemed febrile. There was no vomiting, no past history of ingesting any toxic substance, nor of mumps or any other illness. She had not been immunized against diphtheria. There was no history of a tubercular contact. Previously she had walked well.

On examination the temperature was $101^{\circ}$; she was unable to sit or stand, but seemed mentally lucid. There was slight coryza and cough. Examination of any part of the body provoked screaming; there appeared to be generalized tenderness which included the neck muscles. The neck was slightly stiff and Kernig's sign was doubtfully positive. There was no evidence of weakness of the motor cranial nerves and the fundi appeared normal. In the upper limbs power and tone were normal and tendon jerks were present. The abdominal reflexes were obtained. Both lower limbs were weak and flaccid in all muscle groups, proximal as well as distal. Some active movement was still present. There was no muscular wasting. Knee and ankle jerks were absent. Sensation was difficult to assess but the patient appeared to feel a pinprick. Except for a few rhonchi in the chest, no abnormalities were found in other systems.

INVESTIGATIONS.-Lumbar puncture gave clear cerebrospinal fluid with a pressure of 140 to $180 \mathrm{~mm}$. of water; cells, 2 per c.mm.; protein, $85 \mathrm{mg}$. per $100 \mathrm{ml}$.; Pandy's test for globulin, positive; sugar, $63 \mathrm{mg}$. per $100 \mathrm{ml}$; chlorides, $710 \mathrm{mg}$. per $100 \mathrm{ml}$. The Wassermann reaction was negative, as was culture for tubercle bacilli. Haemoglobin was $64^{\circ}$ \% $(9.5 \mathrm{~g}$. per $100 \mathrm{ml}$.), and a white blood count gave 11,800 per c.mm. (polymorphs $60^{\circ}$, lymphocytes $28^{\circ}{ }_{0}$, monocytes $11^{\circ}$, e esinophils $1^{\circ}{ }_{0}$ ).

A blood culture showed no growth. The Mantoux test was negative down to 1 in 100 .

No porphyrins were detected in the urine. The Paul Bunnell test was negative.

No abnormality was seen in a radiograph of the spine, but doubtful miliary spots not eventually confirmed in further films were seen in a radiograph of the chest.

The Schick test was positive.

Owing to the doubtful $x$-ray findings, intramuscular streptomycin was started in doses of $0.5 \mathrm{~g}$. daily, together with para-aminosalicylic acid, $9 \mathrm{~g}$. daily, continued for 
seven days, also streptomycin, $20 \mathrm{mg}$. intrathecally on three successive days. The cells in the cerebrospinal fluid then rose to 800 per c.mm. on one occasion. This was probably a toxic effect of streptomycin.

In the first week after admission the child was noticed to have slight difficulty in swallowing solid food. She did not choke or regurgitate food through the nose. During the first two weeks weakness of the lower limbs increased until there was scarcely any voluntary movement. The muscles continued to be tender. For three weeks there was occasional slight pyrexia with one rise to $102^{\text {* }}$ associated with cough and rhonchi in the chest on the sixteenth day.

In the third week, slight improvement in power and tone of the lower limbs was evident. Improvement was maintained; in the fifth week the patient could kneel and in the seventh week sit unsupported, stand, or walk holding on to the cot sides. In the tenth week she was able to walk unaided and was discharged in good health with power and tone almost normal. Throughout the illness there was no muscular wasting. She had physiotherapy consisting of assisted active movements and walking lessons. The electrical reactions of the muscles were not done.

When seen two months later she appeared healthy and walked well, apart from slight hyper-extension of the left knee and a valgus left ankle. The knee and ankle jerks remained absent.

Case 2.-A boy aged 3 years was admitted on July 27, 1949, with a history of tonsillitis three weeks before, associated with pain and 'stiffness' in both legs, more marked in the left. In the first two days of the illness he had been febrile. The temperature then remained normal. Two weeks before admission his legs became weak. He was 'crawling on his knees' and could not walk. Pain in the legs continued. One week before admission he began to walk again, but dragged the left leg. He had had measles three months previously. There was no history of tuberculous contact.

On examination the temperature was normal, he looked well nourished and was in good general condition. In the upper limbs there was no wasting or loss of power and the tendon jerks were normal. The right leg appeared normal on examination. No swelling of either knee was now seen. He limped in the left leg on walking, with some instability of the hip joint, hyperextension of the left knee, and eversion of the foot. There was generalized hypotonicity and flabbiness of the muscles of the left lower limb, proximally as well as distally, with doubtful minimal wasting of the left thigh and calf. The knee jerks were present and equal on both sides. The left ankle jerk was absent, the right present. There was a yellow follicular exudate in the throat, with slight enlargement of the tonsillar glands. No cardiac murmur was heard; the heart and other systems were normal on examination.

INVESTIGATIONS.-Lumbar puncture produced clear cerebrospinal fluid under normal pressure: cells, fewer than 1 per c.mm.; protein, $91 \mathrm{mg}$. per $100 \mathrm{ml}$.; Pandy's test, positive. The Wassermann reaction was negative.
The Lange curve was 1123311000 . A white blood count gave 6,100 per c.mm. (polymorphs $77^{\circ}{ }_{0}$, lymphocytes $17^{\circ}$, monocytes $4^{\circ}$, eosinophils $2^{\circ}{ }_{0}$ ).

The Mantoux test $(1: 10,000)$ was negative.

The temperature remained normal except for slight intermittent pyrexia up to $99^{\circ}$ in the first three weeks. Sulphamezathine, $0.5 \mathrm{~g}$. four-hourly, was given during the first six days. The tonsillitis resolved. Physiotherapy, consisting of assisted active movements, was given daily. By the eighth week of admission the muscles of the left lower limb were almost as strong as on the right side, except for slight residual weakness of the left calf and anterior tibial muscles.

After a stay of nine weeks the patient was transferred to the country branch of the Royal National Orthopaedic Hospital. He was there reported as having no significant paralysis apart from some weakness of the left leg below the knee which was expected to recover fully. There was very slight wasting of the left calf and he walked unaided with the left foot in calcaneus. Physiotherapy was continued and on October 9, 1949, he was discharged home.

Case 3.-A girl aged 23 months was admitted to The Hospital for Sick Children, Great Ormond Street, on September 13, 1950, with a history of weakness in the legs.

Three and a half months before admission she became unwilling to walk when taken out and asked to be carried. She had previously walked normally. During the next three weeks she was irritable. Weakness of the legs and difficulty in walking increased gradually until she could not walk or stand at all. On several occasions she fell down when trying to walk. Her appetite was poor and she seemed thinner since the onset of the illness. There was no vomiting and no history of coryza or cough.

These symptoms followed a vesicular rash, which began two weeks previously, on the right knee, fingers and face. At the same time she seemed fretful and feverish. The rash spread, covering the whole face. Penicillin ointment was applied and the eruption cleared in two weeks. The child's mother had a similar vesicle on her wrist at about the same time.

The patient had been immunized against diphtheria and vaccinated, but no injections of any kind had been given recently. There was a past history of rubella. There had been no recent illness. The parents were healthy and there was no history of tubercular contact.

The child had been previously admitted (on July 27, 1950) to a military hospital in Germany, where it was found that she had marked weakness in both lower limbs with tenderness of the feet and absent knee and ankle jerks. No other abnormality was found on examination.

Lumbar puncture produced clear cerebrospinal fluid with cells less than 2 per c.mm., protein $320 \mathrm{mg}$. per $100 \mathrm{ml}$., increased globulin, sugar $70 \mathrm{mg}$., chlorides $740 \mathrm{mg}$. per $100 \mathrm{ml}$., and a sterile culture. Radiography of the spine and skull appeared normal.

Haemoglobin was $98 \%$. A white blood count gave 7,000 per c.mm. (polymorphs $55^{\circ} \%$, lymphocytes $40 \%$, monocytes $5 \%$ ). 
A diagnosis of infective neuritis was made. Slight occasional pyrexia continued for 10 days and then subsided. Physiotherapy was started and there was some general improvement but progress was slow, although she was moving more freely.

After six weeks in hospital in Germany it was decided to send her to England for further observation to exclude cerebral tumour. The cerebrospinal fluid protein level was still high $(300 \mathrm{mg}$. per $100 \mathrm{ml}$.).

On transfer on September 13 to The Hospital for Sick Children, Great Ormond Street, the patient appeared an irritable, well-nourished child, unable to walk, but she could now stand on a broad base.

Clinical examination confirmed the findings already obtained in Germany and the diagnosis of acute infective polyneuritis. There was hypotonia of the lower limbs, which were not wasted. Knee and ankle jerks were still absent and there was considerable tenderness of the feet. She appeared to feel pinprick in the lower limbs. Coordination was normal.

INVESTIGATIONS.-On September 14 lumbar puncture showed clear cerebrospinal fluid: cells, fewer than 1 per c.mm.; protein, $180 \mathrm{mg}$. per $100 \mathrm{ml}$.; Wassermann reaction, negative. At repeat lumbar puncture on September 21 there were no cells and the protein was $160 \mathrm{mg}$.

Further radiographs of the skull and spine remained normal and there was no radiological evidence of metallic deposits in the long bones.

The serum Kahn test was negative.

No antibody to herpes simplex was detected in a serum herpes neutralization test.

No pus cells or protein was found in the urine, which in culture was sterile.

On June 26, 1951, the knee jerks were returning and could just be obtained. The ankle jerks remained absent. There was still no wasting in the legs. It was now four and a half months since the child's legs first became weak and as there was gradual improvement with physiotherapy and gain in weight, she was returned to the hospital in Germany to complete her treatment.

Case 4.-A girl aged $2 \frac{1}{2}$ years was admitted to The Hospital for Sick Children, Great Ormond Street, on September 1, 1950, with a history of weakness in the legs.

Two months before admission she seemed easily tired and slept badly. Her appetite was poor and she looked thinner. She began to complain of pain in the abdomen and legs. Three weeks later she could only walk from room to room. After a further two weeks she would get out of bed, walk a few steps, then lie down until she was picked up. She 'got weak and went off her legs' and was very miserable.

One month before the onset of these symptoms there was a profuse itching rash, consisting of discrete raised spots on the knees and feet. The rash lasted three weeks and was associated with malaise.

The patient had previously been a lively child who walked well. She had been immunized against diphtheria and vaccinated. There had been no other illness.

On examination her temperature was $98^{\circ}$ and pulse
120 per minute. She was pale and miserable with a rather expressionless face and talked in a weak, nasal monotone. She could not sit or stand alone but could walk a few steps if supported.

Examination of the cranial nerves confirmed a mild bilateral facial weakness. This was more evident on the right side and was of a lower motor neuron type. There was marked hypotonia of the neck muscles. Both upper limbs showed generalized flaccidity and hypotonia, more marked in the right limb. There was weakness with minimal wasting. Biceps, triceps and supinator jerks were absent on both sides. The erector spinae and abdominal muscles were weak. Abdominal reflexes were present. The lower limbs were markedly weak, with bilateral foot-drop. The muscles of both calves were tender. There was generalized hypotonia with minimal wasting in the lower limbs. The knee and ankle jerks were absent on both sides. The plantar reflexes were flexor. No cardiac murmur was heard but the heart sounds were poor in quality. Nothing abnormal was found on examination of the lungs or other systems.

INVESTIGATIONS.-Lumbar puncture on September 1 produced clear, colourless cerebrospinal fluid: cells, 1 per c.mm.; protein, $240 \mathrm{mg}$.; sugar, $63 \mathrm{mg}$.; chlorides, $705 \mathrm{mg}$. per $100 \mathrm{ml}$. A repeat lumbar puncture on September 19 gave cells, 7 per c.mm., and protein, $160 \mathrm{mg}$.

A radiograph of the spine showed no abnormality apart from spina bifida of the first sacral segment and incomplete fusion of thoracic vertebrae.

Haemoglobin was $98 \%(13.7 \mathrm{~g}$. per $100 \mathrm{ml}$.) red blood cells $4,870,000$ per c.mm., white blood cells 15,000 per c.mm. (polymorphs $64^{\circ}$, , lymphocytes $33 \%$, eosinophils $3 \%$ ).

A tuberculin jelly test was negative.

A diagnosis of polyneuritis was made and physiotherapy, consisting of assisted active movements, was started. Within two weeks of admission the child had improved generally and the right knee and ankle jerks were faintly present. Eighteen days after admission she seemed happier and her face was more expressive. She was now walking fairly well. The knee and ankle jerks could be obtained on both sides. The child's temperature had remained normal throughout. On September 21 she was discharged home.

When seen as an out-patient one month later she appeared healthy and walked well.

Case 5.-A boy aged 3 years was admitted to The Hospital for Sick Children, Great Ormond Street, on March 8, 1954, with a history of weakness in the legs.

One morning, five weeks before admission, he fell downstairs; no injury was found, but the right leg was subsequently noticed to be weak. Weakness in both legs increased, especially in the 'hip parts', during the next three weeks. The mother noticed when dressing the child that his arms were weak and that he was unable to grip objects firmly. Walking became steadily more difficult until one week before admission he could not rise from the floor, and could only walk a few steps with support. He had slight difficulty in starting micturition. The child's appetite had become very poor. 
There had been no previous illness apart from frequent nasal discharge, occasional mild attacks of asthma and bronchitis, and measles, which was not recent. He had never been immunized against diphtheria or vaccinated.

On examination he was a miserable, rather undernourished child, with profuse nasal discharge, who could not walk without help. The cranial nerves were normal. In the upper limbs there was generalized weakness and hypotonia of all muscle groups, with no wasting. The biceps, triceps and supinator jerks were faintly present. Generalized weakness and hypotonia were also present in the lower limbs and they were tender when touched. Both knee jerks were absent, but the ankle jerks were faintly present. Numerous coarse râles were heard in all areas of the lungs. No other abnormality was found.

INVESTIGATIONS.-Lumbar puncture produced clear cerebrospinal fluid: cells, 0; protein, $70 \mathrm{mg}$; sugar, $64 \mathrm{mg}$.; chlorides, $740 \mathrm{mg}$. per $100 \mathrm{ml}$.

Haemoglobin was $98 \%(13.7 \mathrm{~g}$. per $100 \mathrm{ml}$.) and a white blood count 15,300 per c.mm. (polymorphs $77 \%$, lymphocytes $19^{\circ}$, eosinophils $4^{\circ}$ ).

A tuberculin jelly test was negative.

No abnormality was found in the urine.

A radiograph of the sinuses showed opaque antra, but no abnormality was seen in the chest.

A diagnosis of acute polyneuritis was made and breathing exercises and gentle assisted active movements were started. One week after admission walking had improved, but there was some hyper-extension of both knee joints. Power was increasing in the arms and the chest was clearer. He was transferred to the Hospital's country branch.

When seen there on April 9, 1954, the patient was still weak on his legs but could walk without assistance. His general condition had improved. Slight hypotonia was still present throughout all limbs. Power had increased but was still below normal in all muscle groups. The tendon reflexes remained unchanged and no wasting had developed.

At the time of writing, muscle power continues to improve gradually.

\section{Discussion}

Guillain et al. (1916) gave as criteria of their syndrome motor disturbance with loss of tendon reflexes and preservation of cutaneous reflexes, paraesthesiae with slight objective sensory loss, tenderness of muscles, little change in electrical reaction of muscles and increased protein in the cerebrospinal fluid with no cytological reaction. They said that a good prognosis could be given even in the presence of serious paralysis. As the cause they postulated an infective or toxic agent.

The clinical features of later reports have resembled those described by these authors, with the addition of cranial nerve involvement, notably of the seventh nerve. The onset of paralysis often followed a mild pharyngitis or digestive upset. In Debré's cases the invasive period varied from five to
21 days. Paralysis occurred as a flaccid paraplegia, or sometimes involved only the lower limbs. Sphincter disturbances were sometimes described (Ansay, 1937). The importance of watching for dysphagia and taking prompt measures to prevent aspiration pneumonia was stressed by Debré and Thieffry (1951). Sensory symptoms were often mentioned by older children with the disease.

The features of the Guillain-Barré syndrome have also been reported following diseases such as measles, infective mononucleosis and hepatitis. The aetiology of the syndrome remains uncertain.

The albumino-cytological dissociation was found to be non-specific and occurred in other diseases. Dagnelie (1938) pointed out that this feature might be present in the later stages of poliomyelitis. Van Bogaert et al. (1938) recorded serial levels of cerebrospinal fluid protein in cases of the syndrome. These showed a maximal level between the twentyfifth and forty-fifth days of illness. Debré and Thieffry (1951) stated that the maximal level occurred between the tenth and the twentieth day of onset.

The electrical responses of paralysed muscles have been described as diminished, without any reaction of degeneration.

In most patients who recovered the sequelae were minimal. Tendon jerks were often absent months or years after clinical recovery.

Features resembling acrodynia have been described by some authors in cases of the GuillainBarré syndrome (Van Bogaert et al., 1938; Keizer, 1951). The pathological changes reported have been slight. Degeneration of peripheral nerves has been seen microscopically (Gilpin, Moersch and Kernohan, 1936; Debré and Thieffry, 1951).

Joiner, McArdle and Thompson (1950) studied pyruvate metabolism in an unselected group of patients with polyneuritis. They were able to classify their $\mathbf{4 0}$ cases into those in which the blood pyruvate level was normal and those which showed an abnormal rise of blood pyruvate after a test dose of glucose. Of the latter, some responded to treatment with thiamine. Dimercaprol was given to those who did not respond to thiamine. Pyruvate, formed as an intermediate product in the metabolism of glucose, is known to accumulate if there is a failure of the pyruvate oxidase system, when tissue anoxia results. Known causes are thiamine deficiency and the toxic effect of arsenic and heavy metals. Joiner's series included three cases of infective polyneuritis, but these were already in the stage of recovery. The blood pyruvate level was raised in one, but treatment was not given as the patient was already improving. In the other two 
cases, the blood pyruvate level was normal. Thiamine and dimercaprol have been administered in cases of the Guillain-Barre syndrome on the assumption that a defect in the pyruvate oxidase system might be present in the neurons (Von Hagen and Baker, 1953). Possibly it would be instructive to study pyruvate metabolism in a series of cases of the syndrome in the acute stage.

In the present series the typical features of acute infective polyneuritis were shown. In all five cases the onset of paralysis was gradual and not associated with high temperatures. Paralysis was proximal as well as distal and did not pick out individual muscle groups. Recovery was good and wasting and permanent changes were minimal. There was a monoplegia in one case, two others had a diplegia and two showed quadriplegia, one of these also having a facial diplegia. Three of the five cases described had a preceding or coexisting

TABLE 1

ACUTE INFECTIVE POLYNEURITIS IN CHILDREN

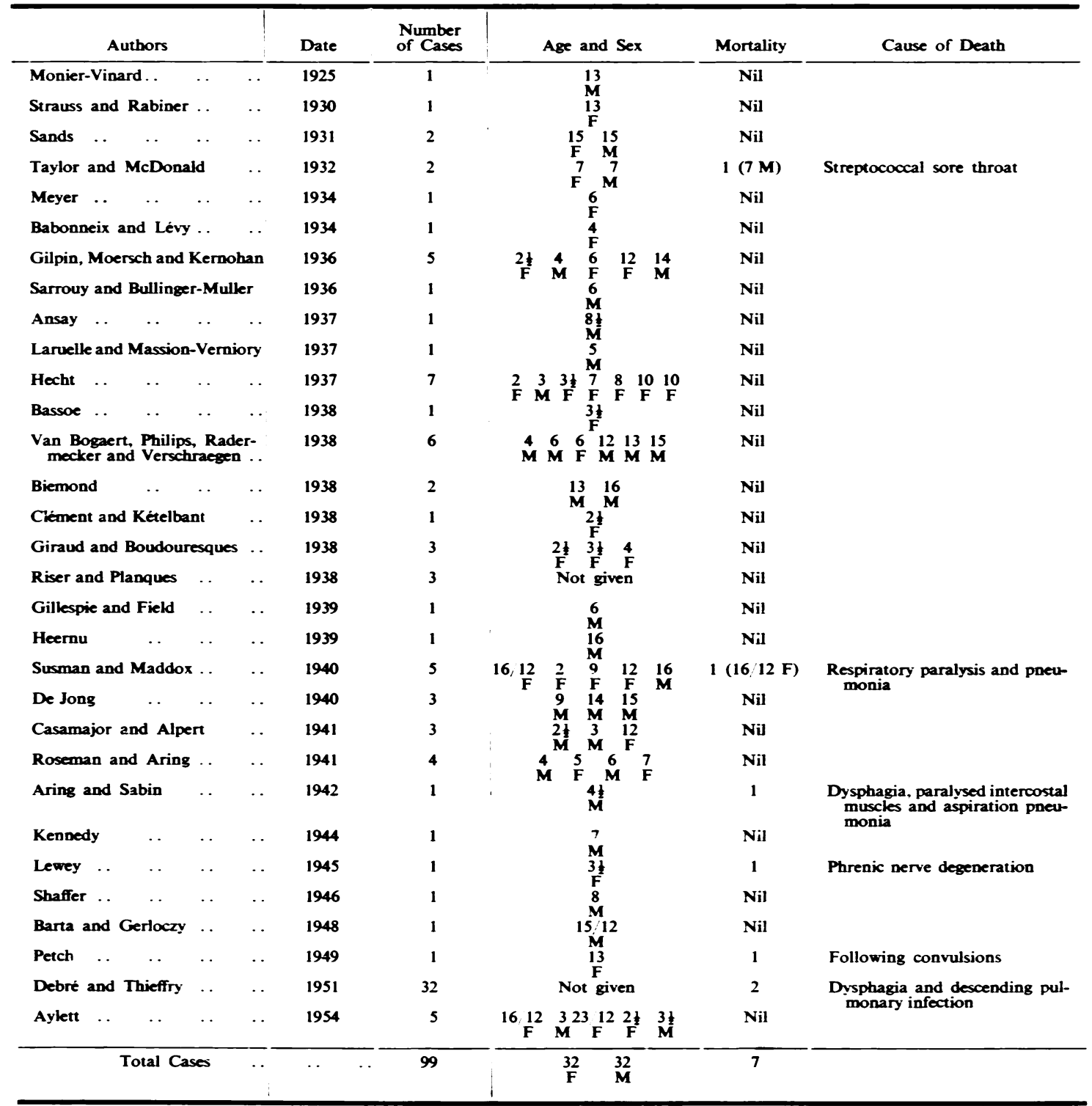


upper respiratory infection, a feature often mentioned in the literature. A rash preceded paralysis in two cases. In Case 3 this was vesicular in type, and generalized herpes simplex was at one time considered a possible cause but no antibodies were found. Rashes do not seem to have been mentioned before as a feature, except the eruption of varicella, which has been described in association with the Guillain-Barré syndrome (Roseman and Aring, 1941; Clément and Kételbant, 1938). The distribution of the rash was not characteristic of varicella in Case 3 of the present series.

All five patients were under the age of 4 years, the youngest being 16 months. There were three girls and two boys. The cerebrospinal fluid showed the typical finding of a normal cell count and raised protein in all.

There was no mortality in this series. This may have been due to the fact that respiratory infection occurred in only two cases (Cases 1 and 5) and was slight. In 99 collected published cases in children with typical features, seven died (Table). Of 64 cases in which age and sex were given, 27 were 5 years or under (about $42 \%$ ) and sex incidence was equal. It seems noteworthy that four of the seven deaths were due to pulmonary infection associated with dysphagia or respiratory paralysis. Of these four children, three were under the age of 2 years. It is possible that early detection of dysphagia with the use of parenteral fluids instead of feeding by mouth, with aspiration of pharyngeal secretions, and the use of antibiotics and a mechanical respirator where appropriate might improve the prognosis in such serious cases.

\section{Summary}

Five cases of acute infective polyneuritis in children are reported.

The subject is briefly reviewed.

Ninety-nine collected published cases in children are tabulated. This collection shows a mortality of about $7 \%$ often associated with pulmonary infection following dysphagia or respiratory paralysis.

I wish to thank Dr. M. Dynski-Klein for permission to publish Cases 1 and 2, Dr. Wyllie for permission to publish Case 3, Dr. P. R. Evans for making available the notes of Cases 4 and 5 for inclusion in this paper, and Dr. W. Sheldon for allowing me to examine Case 5 at Tadworth Court.

\section{References}

Ansay, J. (1937). J. belge Neurd. Psychiar., 37, 311.

Aring, C. D. and Sabin, A. B. (1942). Arch. Neurol. Psychiat., Chicago, 47, 938.

Babonneix, L and Maurice-Lèvy (1934). Gaz. Hóp., Paris, 107, 117

Barta, L. and Gerloczy, F. (1948). Arch. franc. Pediat., 5, 356.

Bassoe, P. (1938). Arch. Path., Chicago, 26, 289.

Biemond, A. (1938). J. belge Neurd. Psychiat., 38, 231.

Bogaert, L. van. Philips, F., Radermecker. J. and M. A. and Verschraegen, T. (1938). Ibid., 38, 151.

Bradford, J. R., Bashford, E. F. and Wilson, J. A. (1918). Quart. J. Med., 12, 88.

Casamajor, L., and Alpert, G. R. (1941). Amer. J. Dis. Child., 61, 99.

Clèment and Kételbant (1938). J. belge Neurol. Psychiat., 38, 240

Dagnelie, J. (1938). Ibid., 38, 282.

Debré, R and Thieffry, S.' (1951). Arch. franc. Pédiat., 8, 357.

De Jong. R. N. (1940). Arch. Neurol. Psychiat., Chicago, 44, 1044.

Gillespie, J. B. and Field, E. H. (1939). J. Pediat., 14, 363.

Gilpin, S. F., Moersch, F. P. and Kernohan, J. W. (1936). Arch. Neurol. Psychiat., Chicago, 35, 937.

Giraud, P. and Boudouresques, J.' (1938). J. belge Neurol. Psychiat., 38, 256.

Guillain, G., Barré, J. A. and Strohl. A. (1916) Bull. Soc. méd. Hop., Paris, 40, 1462.

Hecht, M. S. (1937). J. Pediat., 11, 743.

Heernu (1939). J. belge Neurol. Psychiat., 39, 250.

Holmes, G. (1917). Brit. med. J., 2, 37.

Joiner, C. L., McArdle, B. and Thompson, R. H. S. (1950). Brain, 73, 431 .

Keizer, - (1951). Arch. franc Pédiat., 8. 380.

Kennedy, R. T. (1944). Med. J. Aust., 2, 231.

Laruelle, L. and Massion-Verniory, L.' (1937). J. belge Neurol. Psychiat., 37, 635 .

Lewey, F. H. (1945). J. Pediat., 26, 165.

Meyer, R. (1934). Rev. Neurol., Paris, 41(2), 617.

Monier-Vinard (1925). Ibid., 32(2), 761.

Petch, C. P. (1949). Lancet, 2, 405.

Petch, C. P. (1949). (1938). J. belge Neurol. Psychiat., 38, 264.

Roseman, E. and Aring, C. D. (1941). Medicine, Baltimore, 20, 463.

Sands, I. J. (1931). J. Amer. med. Ass., 96, 23.

Sarrouy and Bullinger-Muller (1936). Bull. Soc. Pédiat., Paris, $34,556$.

Shaffer, J. O. (1946). J. Amer. med. Ass., 131, 285.

Strauss, I. and Rabiner, A. M. (1930). Arch. Neurol. Psychiat., Chicago, 23, 240.

Susman, E. and Maddox, K. (1940). Med. J. Aust., 1, 158.

Von Hagen, K. O. and Baker, R. N. (1953). J. Amer. med. Ass. 151,1465 .

Taylor, E.W. and McDonald, C. A. (1932). Arch. Neurd. Psychiat. Chicago. 27, 79. 